\title{
PENYESUAIAN SOSIAL REMAJA DITINJAU DARI PERAN IBU AYAH DAN KEPERCAYAAN DIRI PADA REMAJA
}

\author{
Ernawati dan Galih Fajar Fadillah \\ Program Studi Bimbingan Konseling Islam, Fakultas Ushuluddin dan Dakwah, \\ Institut Agama Islam Negeri Surakarta \\ E-Mail : ernawatikonseling@gmail.com; Galihfajarf@gmail.com
}

\begin{abstract}
This study aims to determine the relationship between mother's role, father's role and selfconfidence with social adjustment in adolescents. The research subjects of class IX Muhammadiyah Middle School 1 Surakarta numbered 110 people. Data collection uses social adjustment scale, father's role scale, mother's role scale, self-confidence scale. Data analysis calculations used three predictor regression analysis techniques and cross tabulation analysis. From the results of data analysis, there is a significant relationship between father's role, mother's role and self-confidence with social adjustment, which correlates the role of father to social adjustment $=23.8 \%$; mother's role in social adjustment $=$ $16.1 \%$; confidence in social adjustment $=18.1 \%$. The total effective contribution of father's role, mother's role and confidence in social adjustment is $58 \%$.
\end{abstract}

Keywords: social adjustment, father's role, mother's role, self-confidence.

Abstrak: Penelitian ini bertujuan untuk mengetahui hubungan antara peran ibu, peran ayah dan kepercayaan diri dengan penyesuaian sosial pada remaja. Subjek penelitian siswa kelas IX SMP Muhammadiyah 1 Surakarta berjumlah 110 orang. Pengumpulan data menggunakan skala penyesuaian sosial, skala peran ayah, skala peran ibu, skala kepercayaan diri. Perhitungan analisis data menggunakan teknik analisis regresi tiga prediktor dan analisis tabulasi silang. Dari hasil analisis data menunjukkan terdapat hubungan signifikan antara peran ayah, peran ibu dan kepercayaan diri dengan penyesuaian sosial yang nilai korelasi peran ayah terhadap penyesuaian sosial $=23,8 \%$; peran ibu terhadap penyesuaian sosial $=$ 16,1\%; kepercayaan diri terhadap penyesuaian sosial $=18,1 \%$. Total sumbangan efektif peran ayah, peran ibu dan kepercayaan diri terhadap penyesuaian sosial sebesar $58 \%$.

Kata kunci: penyesuaian sosial, peran ayah, peran ibu, kepercayaan diri.

\section{PENDAHULUAN}

Sebagai makhluk sosial yang membutuhkan kehadiran orang lain, dibutuhkan adanya keselarasan diantara manusia itu sendiri. Agar hubungan interaksi berjalan baik diharapkan manusia mampu untuk beradaptasi atau menyesuaikan diri terhadap lingkungan fisik maupun lingkungan sosialnya, sehingga dapat menjadi bagian dari lingkungan tanpa menimbulkan masalah pada dirinya. Dengan kata lain berhasil atau tidaknya manusia dalam menyelaraskan diri dengan lingkungannya sangat tergantung dari kemampuan penyesuaian sosialnya.

Penyesuaian dapat didefinisikan sebagai interaksi yang kontinyu antara diri individu sendiri, dengan orang lain dan dengan dunia luar. Ketiga faktor ini secara konstan mempengaruhi individu dan hubungan tersebut bersifat timbal balik. Dari diri sendiri yaitu jumlah keseluruhan dari apa yang telah ada pada diri individu, tubuh, perilaku dan pemikiran serta perasaan.

Orang lain yaitu orang-orang disekitar individu yang mempunyai pengaruh besar dalam kehidupan individu. 1

Rendahnya kemampuan penyesuaian sosial pada remaja dapat muncul dalam bentuk pelanggaran terhadap aturan, aturan yang berlaku dalam lingkungan keluarganya maupun aturan di lingkungan sekolah. Berdasarkan hasil wawancara yang peneliti lakukan terhadap guru-guru BP di sekolah, pada umumnya siswa yang melakukan pelanggaran adalah mereka yang kurang perhatian dari orang tua atau keluarganya, sedangkan korbannya (misalnya kasus perkelahian, pemalakan adalah siswa yang cenderung pendiam dan kurang percaya diri.

Lebih lanjut guru BP SMP tersebut menjelaskan, umumnya siswa yang menjadi korban adalah anak1 Calhoun, F. J. dan Acoacella J. R. 1995. Psikologi Tentang Penyesuaian Sosial Dan Hubungan Kemanusiaan. Edisi ketiga. (Terjemahan Satmoko). Semarang. IKIP Semarang Press. 
anak kelas VII yang baru masuk, sehingga dalam masa penyesuaian sosial tersebut, anak-anak cenderung masih takut dan merasa rendah diri. Sedangkan pelaku umumnya adalah kakak kelas atau teman satu angkatan yang memiliki kepercayaan diri yang negatif, merasa memiliki kekuasaan, dan ditakuti oleh adik kelas ataupun teman se angkatannya. Perilaku tersebut dapat mempengaruhi siswa lain untuk melakukan pelanggaran di sekolah.

Pelanggaran yang dilakukan usia remaja adalah perkelahian antar remaja atau tawuran. Di kota-kota besar seperti Jakarta, Surabaya, dan Medan, tawuran sering terjadi. Data di Jakarta misalnya (Bimmas Polri Metro Jaya), tahun 1992 tercatat 157 kasus perkelahian pelajar. Tahun 1994 meningkat menjadi 183 kasus dengan menewaskan 10 pelajar, tahun 1995 terdapat 194 kasus dengan korban meninggal 13 pelajar dan 2 anggota masyarakat lain. Tahun 1998 ada 230 kasus yang menewaskan 15 pelajar serta 2 anggota Polri, dan tahun berikutnya korban meningkat dengan 37 korban tewas. Terlihat dari tahun ke tahun jumlah perkelahian dan korban cenderung meningkat. Bahkan sering tercatat dalam satu hari terdapat sampai tiga perkelahian di tiga tempat sekaligus.2. Hal tersebut senada seperti hasil penelitian Nicola, dkk 3yang menunjukkan bahwa $20 \%$ anak-anak termasuk remaja ditemukan berperilaku menyimpang. Sebanyak 13\%sulit untuk dikendalikan oleh orang tua, dan kurang lebih 50\% remaja mengalami kesulitan dan permasalan perilaku.

Wawancara yang peneliti lakukan dengan salah seorang Kepala sekolah SMP swasta di kota Solo menuturkan bahwa orang tua kurang menyadari perannya dalam proses pendidikan anak, sebagain besar dari orang tua apabila telah menyekolahkan anaknya di sekolah tertentu, berarti proses pendidikan anak tersebut telah menjadi tanggung jawab sepenuhnya dari sekolah yang bersangkutan. Kepala Sekolah menambahkan seharusnya tidak demikian, semua itu adalah tanggung jawab orang tua dan sekolah untuk menjalin kerjasama yang baik dalam rangka untuk mendidik si anak. Dengan kerjasama yang baik, diharapkan proses pendidikan bagi si anak akan berjalan baik dan lancar, sehingga harapan orang tua dan sekolah untuk menjadikan anak yang cerdas serta berbudi pekerti yang luhur akan tercapai secara optimal. Sebaliknya apabila orang tua acuh tak acuh terhadap proses pendidikan anak, akan mengakibatkan proses pembelajaran anak di sekolah juga akan terhambat, karena itu muncullah pelanggaran - pelanggaran yang di lakukan oleh siswa di sekolah.

Hasil riset psikologi menyatakan bahwa peran ayah sangat penting dalam pertumbuhan seorang anak. Ikatan emosional antara ayah dan anak ditentukan salah satunya oleh interaksi antara ayah dan anak itu sendiri. Selain ikatan kasih sayang yang tetap terjaga, interaksi yang baik antara anak dan avah ini, dikatakan sangat mempengaruhi kecerdasan 2 Tambunan. 2001. Perkelahian Remaja. Http. www.epsikologi.com.remaja nakal perkelahian remaja.com diakses pada tanggal 3 Maret 2009.

3 Nicola A.C., dkk. 2006. An Evaluation of a Parenting Class Curriculum For Parent Of Young Children. Parenting the Strong Wikked._Springer Science Business Media. LLC. emosional seorang anak yang membuatnya tumbuh menjadi sosok dewasa yang berhasil.4 Lebih lanjut menambahkan saat ini, keluarga-keluarga di dunia sedang mengalami banyak perubahan, mulai perubahan dari kehidupan berkeluarga besar menjadi keluarga inti, meningkatnya jumlah wanita (termasuk ibu) dalam dunia kerja, meningkatnya angka cerai-kawin, meningkatnya jumlah kelahiran tanpa pernikahan, meningkatnya jumlah wanita sebagai orang tua tunggal dan kepala rumah tangga, serta jumlah ayah yang tinggal jauh dari keluarga. Fenomena-fenomena tersebut, menurunkan peran ayah dalam keluarga sebagai pendidik, kepala rumah tangga, dan pencari nafkah.

Selain peran ibu dan peran ayah, faktor internal yang berkaitan dengan penyesuaian sosial pada remaja adalah kepercayaan diri.5 menjelaskan kegagalan atau keberhasilan seseorang dalam penyesuaian sosial ditentukan pula oleh konsep dirinya. Konsep diri yang positif akan memuculkan kepercayaan diri yang baik yang mengarah pada perilaku yang baik. Dan sebaliknya konsep diri negatif akan memunculkan rendahnya kepercayaan diri dan dapat mengarah pada perilaku yang buruk.

Kepercayaan diri merupakan keyakinan dalam diri seseorang untuk dapat menangani segala sesuatu dengan tenang. Kepercayaan diri merupakan keyakinan dalam diri yang berupa perasaan dan anggapan bahwa dirinya dalam keadaan baik sehingga memungkinkan individu tampil dan berperilaku dengan penuh keyakinan. 6

\section{METODE PENELITIAN}

Penelitian ini menggunakan pendekatan kuantitatif. Identifikasi variabel penelitian

variabel independen: 1). Peran Ayah, 2). Peran Ibu, 3). Kepercayaan Diri. Sedangkan variabel dependen: penyesuaian sosial. Subjek Penelitian. Subjek penelitian adalah siswa-siswi kelas IX SMP Muhammadiyah 1 Surakarta berusia 13-16 tahun, tinggal bersama orang tua. Jumlah sampel penelitian sebanyak 110 orang.

Metode Pengumpulan data. Metode pengumpulan data yang digunakan dalam penelitian ini adalah dengan menggunakan skala penyesuaian sosial, skala peran ayah, skala peran ibu, skala kepercayaan diri. Skala penyesuaian sosial disusun berdasarkan teori yang dikemukakan oleh7 meliputi aspek-aspek self knowledge, self objectifity, self development, self satisfaction.

Skala peran ayah disusun berdasarkan teori yang dikemukakan oleh 8 meliputi aspek-aspek provider, 4 Basuki S, 2009. Peranan Ayah dalam Homescholling. Diakses dari http.www.e magazine.com htm pada tanggal 1 maret 2009. 5

6 Hambly, K.1987. Bagaimana Meningkatkan Kepercayaan Diri? (Terjemahan F.X Budiyanto). Jakarta : Arcan

7 Pramadi A.1996. Hubungan Antara Kemampuan Penyesuaian sosial Terhadap Tuntutan Tugas Dan Hasil Kerja. ANIMA (Jurnal Penelitian Kajian Ilmiah Fakultas Psikologi Universitas Surabaya).

8 Dagun, S.M. 1990. Psikologi Keluarga (Peranan Ayah dalam Keluarga). Jakarta : Rineka Cipta. 
protector, desion maker, child specialiser \& educator, nurtured mother. Skala peran ibu disusun berdasarkan aspek peran ibu menurut BKKBN yaitu peran sebagai : pendidik, pendorong, panutan, pengawas, konselor, teman, komunikator. Skala kepercayaan diri disusun berdasarkan teori 9meliputi aspek: keyakinan akan kemampuan diri, optimis, objektif, bertanggungjawab, rasional dan realistis. Sedangkan metode analisis data. Perhitungan analisis data menggunakan teknik analisis regresi tiga prediktor.

Pengumpulan data dalam penelitian ini dilaksanakan melalui proses sebagai berikut:
a. 8 Maret 2011 permohonan ijin penelitian
b. 9 Maret 2011 penyerahan surat ijin dan proposal penelitian
c. 9-10 Maret 2011 pengumpulan data uji coba
d. 6-7 April 2011 pengumpulan data penelitian

Pada pembagian skala peneliti menekankan kepada para subjek agar mengisi skala dengan sungguh-sungguh dan sesuai dengan keadaan yang dirasakan. Berdasarkan 110 eksemplar masingmasing skala yang dibagikan kepada subjek, hanya 106 yang terkumpul dan memenuhi syarat untuk dianalisis. Setelah data terkumpul selanjutnya dilakukan skoring.

\section{HASIL DAN PEMBAHASAN}

Berdasarkan hasil analisis diperoleh nilai korelasi $(R)=0,545 ; p=0,000 \quad(p<0,01)$; Rsquare $=0,297$. F reg $=14,355$ Berarti ada hubungan yang sangat signifikan antara peran ayah, peran ibu dan kepercayaan diri dengan penyesuaian sosial pada remaja di SMP Muhammadiyah 1 Surakarta.

Berdasarkan persamaan koefisien regresi yang diperoleh sebagai berikut :

$\mathrm{Y}=25,445+0,375 \times 1+0,000 \times 2+0,268 \times 3$.

Hasil persamaan regresi diperkuat oleh nilai uji - t, yaitu nilai yang menunjukkan korelasi parsial antara variabel bebas dengan variabel tergantung, adapun hasilnya sebagai berikut:

1) Nilai $t(x 1)=0,3876 p=0,000(p<0,01)$

Artinya secara parsial ada korelasi yang sangat signifikan antara variabel peran ayah dengan penyesuaian sosial dengan mengendalikan variabel peran ibu dan kepercayaan diri.

2) Nilai $\mathrm{t}(\mathrm{x} 2)=0,001 ; \mathrm{p}=0,999(\mathrm{p}>0,01)$

Artinya secara parsial tidak ada korelasi antara variabel peran ibu dengan penyesuaian sosial dengan mengendalikan variabel peran ayah dan kepercayaan diri.

3) Nilai t $(x 3)=2,012 ; p=0,047(p<0,05)$

Artinya secara parsial ada korelasi yang signifikan antara variabel kepecayaan diri dengan penyesuaian sosial dengan mengendalikan variabel peran ayah dan peran ibu.

Hasil analisis diperoleh nilai Coefficients agung

Correlation $=0,488 ;$ signifikansi $(\mathrm{p})=0.000 ; \quad(\mathrm{p}$ $<0,01$ ) berarti ada hubungan positif yang sangat signifikan antara peran ayah dengan penyesuaian diri. Nilai Coefficients Correlation $=0,401$; signifikansi $(\mathrm{p})=0,000(\mathrm{p}<0,01)$ berarti ada hubungan positif yang sangat signifikan antara peran ibu dengan penyesuaian diri. Nilai Coefficients Correlation $=0,426$; signifikansi $(\mathrm{p})=0,000(\mathrm{p}<0,01)$ berarti ada hubungan positif yang sangat signifikan antara kepercayaan diri dengan penyesuaian diri.

Peran ayah terhadap subjek penelitian secara umum tergolong sedang, ditunjukkan dengan nilai mean empirik $(\mathrm{ME})=46,93$ dan mean hipotetik $(\mathrm{MH})=45$. Peran ibu terhadap subjek penelitian tergolong sedang, nilai mean empirik $(\mathrm{ME})=48.69$ dan mean hipotetik $(\mathrm{MH})=45$. Kepercayaan diri subjek penelitian tergolong sedang, nilai mean empirik $(\mathrm{ME})=52,96$ dan mean hipotetik $(\mathrm{MH})=$ 47,5. Penyesuaian sosial subjek penelitian tergolong sedang, nilai mean empirik $(\mathrm{ME})=67,60$ dan mean hipotetik $(\mathrm{MH})=67,5$.

Sumbangan efektif peran ayah terhadap penyesuaian sosial $=23,8 \%$ ditunjukkan dengan nilai Rsquared $=0,238$ dan peran ibu terhadap penyesuaian sosial $=16,1 \%$ yang ditunjukkan dengan nilai nilai Rsquared $=0,161$. Sumbangan efektif kepercayaan diri terhadap penyesuaian sosial $=18,1 \%$ yang ditunjukkan dengan nilai nilai Rsquared $=0,181$. Total sumbangan efektif peran ayah, peran ibu dan kepercayaan diri terhadap penyesuaian sosial sebesar $58 \%$.

\section{Tabel 1 \\ Rangkuman Kategori, Frekuensi dan Prosentase Subjek Penelitian}

\begin{tabular}{|c|c|c|c|c|c|}
\hline \multirow{2}{*}{ Variable } & \multicolumn{5}{|c|}{ Frekuensi/Prosentase } \\
\cline { 2 - 6 } & S.rendah & Rendah & Sedang & Tinggi & S.tinggi \\
\hline \multirow{2}{*}{$\begin{array}{c}\text { Peran } \\
\text { Ayah }\end{array}$} & 0 & 16 & 52 & 37 & 1 \\
\cline { 2 - 6 } & $0 \%$ & $15,10 \%$ & $49,10 \%$ & $34,90 \%$ & $0.90 \%$ \\
\hline \multirow{2}{*}{$\begin{array}{c}\text { Peran } \\
\text { Ibu }\end{array}$} & 0 & 7 & 53 & 46 & 0 \\
\cline { 2 - 6 } & $0 \%$ & $6,60 \%$ & $50,00 \%$ & $43,90 \%$ & $0 \%$ \\
\hline \multirow{2}{*}{\begin{tabular}{c} 
K.Diri \\
\cline { 2 - 6 }
\end{tabular}} & $0 \%$ & $4,70 \%$ & $50,90 \%$ & $37,70 \%$ & $6,60 \%$ \\
\hline \multirow{2}{*}{\begin{tabular}{c} 
P.Sosial \\
\cline { 2 - 6 }
\end{tabular}} & $0,90 \%$ & $19,80 \%$ & $51,90 \%$ & $26,40 \%$ & $0,90 \%$ \\
\hline
\end{tabular}

\section{Keterangan:}

- $\quad$ Tidak ada subjek penelitian yang memiliki kategori sangat rendah pada variabel peran ibu, peran ayah dan kepercayaan diri

- Tidak ada subjek penelitian yang memiliki kategori sangat tinggi pada variabel peran ibu 
Hasil analisis data menyatakan ada hubungan yang sangat signifikan antara peran ayah dengan penyesuaian sosial. Ada hubungan yang sangat signifikan antara peran ibu dengan penyesuain sosial. Ada hubungan yang sangat signifikan antara kepercayaan diri dengan penyesuain sosial pada remaja. Dan ada hubungan antara Peran ayah,Peran Ibu, dan kepercayaan diri pada penyesuaian sosial pada remaja.

Hasil penelitian ini sesuai dengan beberapa pendapat yang telah dikemukakan oleh para ahli 10yang mengemukakan bahwa Proses penyesuaian sosial pada individu tidaklah mudah. Hal ini karena didalam kehidupannya manusia terus dihadapkan pada pola-pola kehidupan baru dan harapan-harapan sosial baru. Periode penyesuaian sosial ini merupakan suatu periode khusus dan sulit dari rentang hidup manusia. Manusia diharapkan mampu memainkan peran-peran sosial baru, mengembangkan sikapsikap sosial baru dan nilai-nilai baru sesuai dengan tugas-tugas baru yang dihadapi .

Disebutkan juga oleh 11bahwa seperti halnya proses penyesuaian sosial yang sulit yang dihadapi manusia secara umum, para remaja juga mengalami proses penyesuaian sosial dimana proses penyesuaian sosial pada remaja ini merupakan suatu peralihan dari satu tahap perkembangan ketahap berikutnya. Dalam periode peralihan ini terdapat keraguan akan peran yang akan dilakukan, namun pada periode ini juga memberikan waktu kepada remaja untuk mencoba gaya baru yang berbeda, menentukan pola perilaku, nilai dan sifat yang paling sesuai dengan dirinya. Dengan kata lain hal ini merupakan proses pencarian identitas diri yang dilakukan oleh para remaja. Sebegitu pentingnya masa remaja, tentu saja sangat dibutuhkan peran penting orang tua yaitu ayah dan ibu untuk dapat mengantarkan para remaja untuk menjadai pribadi yang mampu menyesuiakan diri di lingkungan sosialnya.

Berdasarkan uji-t : secara parsial ada korelasi yang sangat signifikan antara variabel peran ayah dengan penyesuaian sosial dengan mengendalikan variabel peran ibu dan kepercayaan diri. Tidak ada korelasi antara variabel peran ibu dengan penyesuaian sosial dengan mengendalikan variabel peran ayah dan kepercayaan diri. Ada korelasi yang signifikan antara variabel kepecayaan diri dengan penyesuaian sosial dengan mengendalikan variabel peran ayah dan peran ibu.

Selain peran ibu dan peran ayah, faktor internal yang berkaitan dengan penyesuaian sosial pada remaja adalah kepercayaan diri.12Menjelaskan

\footnotetext{
10 Hurlock, E.B. 1993. Psikologi Perkembangan Suatu Pendekatan Rentang Kehidupan. Alih Bahasa : Istiwidawati. Jakarta. Erlangga Gilmer, 1984. Applied Psychology Adjusmrnt in Living and Work (second edition) Tata mc. Graw Hill Publishing Company ltd

11 Hurlock, E.B. 1993. Psikologi Perkembangan Suatu Pendekatan Rentang Kehidupan. Alih Bahasa : Istiwidawati. Jakarta. Erlangga Gilmer, 1984. Applied Psychology Adjusmrnt in Living and Work (second edition) Tata mc. Graw Hill Publishing Company ltd

12 Hurlock, E.B. 1993. Psikologi Perkembangan Suatu Pendekatan Rentang Kehidupan. Alih Bahasa : Istiwidawati. Jakarta. Erlangga Gilmer, 1984. Applied Psychology Adjusmrnt in Living and Work (second edition) Tata mc. Graw Hill
}

kegagalan atau keberhasilan seseorang dalam penyesuaian sosial ditentukan pula oleh konsep dirinya. Konsep diri yang positif akan memuculkan kepercayaan diri yang baik yang mengarah pada perilaku yang baik. Dan sebaliknya konsep diri negatif akan memunculkan rendahnya kepercayaan diri dan dapat mengarah pada perilaku yang buruk.

Kepercayaan diri merupakan keyakinan dalam diri seseorang untuk dapat menangani segala sesuatu dengan tenang. Kepercayaan diri merupakan keyakinan dalam diri yang berupa perasaan dan anggapan bahwa dirinya dalam keadaan baik sehingga memungkinkan individu tampil dan berperilaku dengan penuh keyakinan 13

Hasil analisis diperoleh nilai Coefficients Correlation $=0,488 ;$ signifikansi $(\mathrm{p})=0.000 ; \quad(\mathrm{p}$ $<0,01$ ) berarti ada hubungan positif yang sangat signifikan antara peran ayah dengan penyesuaian diri. Nilai Coefficients Correlation $=0,401$; signifikansi $(p)=0,000(p<0,01)$ berarti ada hubungan positif yang sangat signifikan antara peran ibu dengan penyesuaian diri. Nilai Coefficients Correlation $=0,426$; signifikansi $(p)=0,000(p<0,01)$ berarti ada hubungan positif yang sangat signifikan antara kepercayaan diri dengan penyesuaian diri.

Peran ayah terhadap subjek penelitian secara umum tergolong sedang Peran ibu terhadap subjek penelitian tergolong sedang. Kepercayaan diri subjek penelitian tergolong sedang. Penyesuaian sosial subjek penelitian tergolong sedang.

Sumbangan efektif peran ayah terhadap penyesuaian sosial $=23,8 \%$; peran ibu terhadap penyesuaian sosial $=16,1 \%$; Sumbangan efektif kepercayaan diri terhadap penyesuaian sosial = $18,1 \%$. Total sumbangan efektif peran ayah, peran ibu dan kepercayaan diri terhadap penyesuaian sosial sebesar $58 \%$.

Berdasarkan hasil analisis data disimpulkan bahwa, peran ayah, peran ibu dan kepercayaan diri secara langsung berpengaruh terhadap penyesuaian sosial. Peran ayah dan ibu harus dimaksimalkan agar dapat membantu remaja untuk mampu menyesuaikan diri di lingkuangn sosialnya. Sedangkan faktor dari dalam diri remaja yaitu kepercayaan diri juga sangat penting untuk dapat membantu remaja mudah beradaptasi atau bersosialisasi sehingga diharapkan mampu menyesuaiakn diri dilingkungan sosial yang baru sekalipun.

Hasil penelitian menunjukkan ada hubungan yang sangat signifikan antara peran ayah, peran ibu dan kepercayaan diri dengan penyesuaian sosial pada remaja di SMP Muhammadiyah 1 Surakarta, namun penelitian ini masih terdapat beberapa kekurangan yaitu :

1) Generalisasi dari hasil penelitian ini terbatas pada populasi dimana penelitian dilakukan yaitu SMP Muhammadiyah 1 Surakarta, sehingga hasil kesimpulan kurang dapat digeneralisasikan pada tempat yang lain tanpa melakukan penelitian kembali.

Publishing Company ltd

13 Hambly, K.1987. Bagaimana Meningkatkan Kepercayaan Diri? (Terjemahan F.X Budiyanto). Jakarta : Arcan 
2) Ruang lingkup dan karakteristik penelitian ini terbatas hanya pada a) remaja, b) usia 13-16 tahun, c) tinggal bersama orang tua

3) Metode pengumpulan data yang berupa self report. Meski sah secara metode, namun evaluasi terhadap sikap dan perilaku oleh subjek sendiri tidak bisa lepas dari kemungkinan terjadinya bias subyektivitas, yaitu kecenderungan untuk lebih menonjolkan sisi positif dari kepribadian subjek.

4) Tidak diketahuinya variasi yang mungkin terjadi akibat kontribusi variabel lain, misalnya kemandirian status sosial ekonomi, motivasi berprestasi, dan lain sebagainya karena analisis penelitian ini tidak melibatkan berbagai faktor tersebut

\section{KESIMPULAN}

Ada hubungan positif yang signifikan antara peran ayah, peran ibu, kepercayaan diri dengan peneyesuaian sosial dengan nilai $r$ sebesar 0,545 dengan $\mathrm{p}=0,000(\mathrm{p}<0,01$ artinya semakin tinggi peran ayah, peran ibu, dan kepercayaan diri maka semakin tinggi penyesuian sosial

1) Peranan atau sumbangan efektif peran ayah terhadap penyesuaian sosial remaja sebesar $23,8 \%$, peran ibu sebesar $16,1 \%$ kepercayaan diri sebesar 18,1\%, sehingga total sumbangan efektif peran ayah, peran ibu dan kepercayaan diri terhadap penyesuaian sosial sebesar 58\% Hal ini berarti masih terdapat $42 \%$ faktor-faktor lain yang mempengaruhi penyesuaian sosial selain variabel peran ayah, peran ibu kepercayaan diri seperti peran nenek, peran kakek, motivasi, kepribadian, inteligensi, dan lain sebagainya.

2) Nilai rerata empirik variabel peran ayah sebesar 46,93 dan rerata hipotetik sebesar 45, hal ini menunjukkan bahwa peran ayah pada subjek penelitian tergolong sedang. Nilai rerata empirik variabel peran ibu sebesar 48,69 dan rerata hipotetik sebesar 45 , hal ini menunjukkan bahwa peran ibu pada subjek penelitian tergolong sedang. Nilai rerata empirik variabel kepercayaan diri sebesar 52,96 dan rerata hipotetik sebesar 47,5 hal ini menunjukkan bahwa peran ayah pada subjek penelitian tergolong sedang.

3) Berdasarkan perhitungan diketahui variabel penyesuaian sosial memiliki nilai rerata empirik sebesar 67,60 dan rerata hipotetik sebesar 67,5 yang berarti penyesuain sosial pada subjek penelitian tergolong sedang.

Untuk sarjana psikologi atau psikolog sebagai peneliti selanjutnya hendaknya meningkatkan kualitas penelitian lebih lanjut khususnya yang berkaitan dengan peran ayah, peran ibu dan kepercayaan diri serta penyesuaian sosial pada remaja. Peneliti lain diharapkan menyempurnakan hasil penelitian ini dengan cara menambah variabel-variabel lain yang belum diungkap misalnya peran nenek, kakek, guru, inteligensi, lingkungan sekolah dan pergaulan, kondisi psikis dan fisik.

\section{DAFTAR PUSTAKA}

Basuki S, 2009. Peranan Ayah dalam Homescholling. Diakses dari http.www.e magazine.com htm pada tanggal 1 maret 2009 .

Calhoun, F. J. dan Acoacella J. R.1995. Psikologi Tentang Penyesuaian Sosial Dan Hubungan Kemanusiaan. Edisi ketiga. (Terjemahan Satmoko). Semarang. IKIP Semarang Press.

Dagun, S.M. 1990. Psikologi Keluarga (Peranan Ayah dalam Keluarga). Jakarta : Rineka Cipta.

Daradjat, Z. 1992. Kesehatan Mental. Jakarta: Gunung agung

Hambly, K.1987. Bagaimana Meningkatkan Kepercayaan Diri? (Terjemahan F.X Budiyanto). Jakarta : Arcan

Hurlock, E.B. 1993. Psikologi Perkembangan Suatu Pendekatan Rentang Kehidupan. Alih Bahasa : Istiwidawati. Jakarta. Erlangga Gilmer, 1984. Applied Psychology Adjusmrnt in Living and Work (second edition) Tata mc. Graw Hill Publishing Company ltd

Nicola A.C., dkk. 2006. An Evaluation of a Parenting Class Curriculum For Parent Of Young Children. Parenting the Strong Wikked. Springer Science Business Media. LLC.

Pramadi A.1996. Hubungan Antara Kemampuan Penyesuaian sosial Terhadap Tuntutan Tugas Dan Hasil Kerja. ANIMA (Jurnal Penelitian Kajian Ilmiah Fakultas Psikologi Universitas Surabaya).

Tambunan. 2001. Perkelahian Remaja. Http. www.epsikologi.com.remaja nakal perkelahian remaja.com diakses pada tanggal 3 Maret 2009. 